\title{
Analysis of the Confrontational Relationship of US and Iran
}

\author{
Zichen $\mathrm{Jia}^{1, \mathrm{a}}$
}

\begin{abstract}
International Business, Southwestern University of financing and economics, Chengdu, Sichuan, 610000, China
Corresponding author's e-mail: angela@cas-harbour.org
\end{abstract}

\begin{abstract}
In this article, we analyze the reasons behind current nervous relationship of US-Iran and propose some valid methods to solve this tension. By selecting authoritative articles and some latest news from the website and analyzing the various factors which affect the nervous relationship, we eventually draw the conclusion that economical, political, cultural, international factors all lead to this adversarial relation, then we can mollify this realtionship through pushing for a deal to denuclaerize Iran, respecting local belief, retreating armies from Iran, providing rudimentary education assitance and infrastracture to Iran. Only by adopting one or two of these methods can the nervous realtionship between U.S. and Iran be mitigated and the regional stability of the middle East can be achieved.
\end{abstract}

Keywords : oil reserve, military intervention, value system, Middle East, denuclearization, national strategy

\section{INTRODUCTION}

Currently, American government continues to adopt a traditional coercion policy on Iran, bringing extensive assault to this country. In January $3^{\text {rd }}$ this year, American army attacked the Baghdad international airport to kill an advanced Iran military commander, Qassim sulermani. After that issue, the Iranian government highly indicted the behavior of America and intimidated America that it will adopt some extreme measures to revenge for America. In the following, the whole America was stuck in high panic and American government put the army on alert. Some review articles even predicted that it was the blasting fuse of the world war III.

The provocation is assumed to be originated from Iranian president Khamenei, who said to Trump: you can do nothing. Out of the anger and domestic interest, Trump launched this assault. Although this affair seems to be an occasional provocation between two countries' leaders, this accidental event has its inherent historical necessity due to the long-term hostility between these two countries. In 1979, the Iranian Revolution was broken in Iran and Iranian government emphasized that they ought to output the fundamentalism of the Iranian Revolution to all the Iranian countries. It publicly called upon Shiah, which occupied 60 percent of Iraqi population to proceed "Iranian revolution". At that moment, America provided military equipment to Saddam's government and buttressed it to lead off an attack to the controversial region, the shatt al-arab, in order to constrain the nascent Iranian government [1]. After that issue, America and Iran became more antagonistic. Moreover, the religion of Iran and America have an absolute collision which causes the relationship between America and Iran more irreconcilable.

To deeply probe the reasons behind the current America-Iran relations, this paper and analyze complex situation of the middle east. Based on the analysis, it provides recommendations to mollify the bilateral relationship, which are expected to have a propitious influence on easing the international and regional situation, preventing war, and saving the peace of the whole world.

\section{REASONS}

\subsection{Conflict of economic benefits in Iran}

Growth of Iranian oil revenue is shaking U.S. economic domination by detaching from the trade system of petrol and U.S. dollar [2]. The core competition of modern countries is the resource and the oil reserve is a key factor for a country's military power and economic development. In fact, Iran has the fourth largest oil reserve in the world. As the world's oil price growing increasingly faster, some prosperous countries, especially some western countries focus on the middle East to seize the oil resource. In particular, America wants to control this country's abundant oil reserve by sighing some unfair treaties or launching some campaigns in order to prosper its domestic economy. So why America particularly sanction Iran in the middle East although Iran does not have the most abundant oil?

This phenomenon is mainly because Iran does not want to sacrifice its own interest to make cooperation with the western world, especially America, in the oil trading and thus Iran receives no economical assistance from the western world. For America, however, it does not want to compromise its own economical interest in the middle East 
because this place's oil reserve may bring large benefit to the U.S. economy, no matter in the finance or the resource. So America adopts some measures with western countries to sanction this poor country, such as making the oil price lower in Iran and blocking the passage of the transportation of oil from Iran [3]. As a result, these sanctions bring about the lower market share of Iranian oil which exacerbate Iranian economy. Nearly all of the economical factors in Iran have been influenced by this economical intervention, such as the export, the financing, the unemployment rate. Eventually, the intervention of the western world in the oil resource may make the economy more roil and the inequality in the Iranians' income may become larger and larger, leading to the unstable Iranian society [4].

Facing such a dilemma, Iranians have taken some economic countermeasures, such as preventing oil trading with the western countries, raising export prices to preserve its local economic status, which seriously infringe the economic interest of western countries, especially America. Then the western countries may aggravate the sanction and Iran will adopt more countermeasures. Gradually, the poor Iranian citizens may be disgusted with the western world and the Iranian government may change its original spending behavior on some issues, such as education, entertainment to remedy the lose in the oil price [5].

Eventually, Iran seems plain to find ways to get rid of the control of the western world and go against sanctions without the international support. Besides, the two countries become more antagonist and the tension finally multiply the discontent of Iranian citizens and countermeasures from Iranian government; for an instance, fighting against the control and obstruction from the western world.

\subsection{Military intervention from western countries in the middle East}

After the World War II, America enlarges its military influence in the Middle East and intervene the regional situation, making the relationship between America and Iran worse, even leading to the two countries proceed some military actions to preserve their own interest in the Middle East. Every year, America and his allied forces will hold some joint military drill near Iranian national borders which seriously intimidating the security of Iran. Meanwhile, America launches numerous battles in the Middle East to establish its authority and prestige in that place.

For example, in 1990, to recover the sovereignty of Kuwait, America and its allies launched the Iraq War. This war seriously destroyed the military force of Saddam hussein regime; in the meantime, America fostered another government in Iraq and enhanced its own sphere of influence in this region. As Iran borders Iraq and they have similar race and religious belief. That affair makes the Iran-America relations worse [6].
To revenge Americans' military action in the middle East, some extremists launched numerous terrorist attack in America, such as the 911 event. After that issue, American army entered Afghan to fight against terrorism lasting for 10 years. In 2003, America conducted unilateral military strikes against Iraq to restrain the research of weapons of mass destruction in Iraq. Although all of these wars are declared with some righteous reasons, including the preservation of the world peace and fighting against terrorism, it simultaneously emphasizes its domestic belief and value as well as imposes that value on the citizens in Iran and other countries, which finally triggers the formation and prevailing resentment of local citizens and the instability atmosphere in the middle East.

Thus, the forceful military intervention brings lots of damage to both sides, including the damage to the Iranian infrastructure, pressure of public opinions, U.S. solider causalities, the increase of Iranian military defense expenditure, etc. Eventually, the U.S. military intervention can make the situation in the middle East more complex and turbulent and the U.S.-Iran relation more complex and irreconcilable.

\subsection{The collision of value system}

It has long been argued that the tension of these two countries derived from the discrepancy of value system. To some extent, the huge ideological differences leads to the urgent and unstable situation in Iran.

For America, it wants to imposes on the middle East its own value system, the notion of freedom, universal love, and equality with American characteristics. Besides, America purports that the whole world ought to obey the regulation of the international world and it acts as a supervisor to point out the misconduct of the members in the international world. When Iran government considers that they ought to research some weapons of mass destruction to protect their own interests and resist the invasion of the western world, America and its allies reject these actions and, for example, urges Iran to terminate its nuclear test for the sake of world peace.

But for Iranians, it is exactly that they need the weapon of mass destruction to protect their national security and fight against the intervention from the western world. Bombast from America and its allies is not thing but that imposing their value system on other countries. Both of the two value system has its own validity and we can hardly make a sound judgment.

In addition, the religious difference can also lead to the collision between two countries. In the middle East, some terrorists respect the value system of Islam. They believe that they can get the permission to heaven if they sacrifice themselves for the interest of their country. So we can see some terrorists who become bomb hacker and rushes to the crowd, which creates panicky and casualties to achieve so-called national pride and preach doctrine [7]. The ideology has rooted in their mind and we can not easily alter that thought. While in the western world, they believe this action is totally reprehensible and unjustifiable 
because the action causes a wide range of casualties of some innocent citizens and disturb the stability of the whole world. Then these countries will launch some war and assault to fight against the uncourteous country which sponsors the terrorism. The invaded countries may then fight back to preserve its domestic interest. Eventually, the whole invasion and anti-invasion formulates a vicious cycle which may finally become a more severe and unpredictable factor

\subsection{Impecunious local economy and uncultured local people}

Unlike some other countries in the middle East, like Dubai, Baharin, which have fairly wealthy citizens and positive international relations, Iranian citizens have a low living quality and poor economy [8]. Under the behindhand local economy, Iranian citizens with low literacy level are easily affected by extreme propaganda in a brainwashing way. Compared with the more advanced economy and brilliant people in developed countries, citizens in Iran have received a less advanced education. With weak discernment and judgment, bottom Iranians are seduced by some extreme ideology,such as creating some terrorist attacks to get the permission to heaven, and a monstrous patriotism, such as only concerning about their own country's interest and disregarding other country's interest. In fact, nearly all of the extremists who sacrifice their lives and participate in some terrorism or other blinded patriotic actions are those with a low literacy according to some surveys. Eventually, the blind actions may bring large casualties to other countries and some moral insanity.

Moreover, the bleak local economy and low industrialization also responsible for the permeation of terrorism and trigger of sensitive patriotic nerves. In other word, the more uncultured and unstable of a region, the more possibility that terrorism will gain its market and persuade the local people to follow the extreme Islamic belief: preserving their own right and attack some innocent people in other countries to get their soul saved, (flying into the heaven when they died). Unexpectedly, some middle East governments, such as Iran, even support some sort of terrorism to drag their country out of the poverty and revenge some countries who choke the local development. From one point, that is one reason why America chooses to fight against Iran and the relationship between these two countries become worse.

Finally, the lack of peace education in Iran may also cause the local people more susceptible to the intervention of other countries. They choose to fight back rather than negotiating with these countries, which may finally disturb the U.S.-Iran relation [9].

\subsection{National strategy of America}

American global strategy makes the regional situation more complex. After the world war II, America has become the most progressive and powerful country in the world. It wants to confirm to other countries how powerful it is. So Americans are always eager to propagate their national value to the other parts of the world and punish some other countries who violate their own belief or the international regulations.

But with the arrival of the 21 st century, many nascent countries come into being and some developing countries have more potential than old capitalist countries. For example, China gains its quickest development in economy since 2000 and it has already become the second prosperous country in the world. Some economists even predict that the overall GDP of China will finally exceed America in 2027. Moreover, some other countries, like Russia, Germany, India, Japan experience a rapid development and the whole world emerges with numerous strong countries. America has lost its extreme advantage over other countries and it has to admit the diversity of the international countries.

Although America has to accept this unprecedented trend, it still publicizes its own belief and restrain other promising countries' development. And the middle East is one of the battlefields it chooses to confront with some other countries, such as China, Russia. In the article Historic US-Iran Relations: Revisiting Ideology and Geostrategy, Lubna Abid Ali said that America just revisit the ideology, which contains the accomplishment and advocation of America dream and geostrategy, which contains enhancing their own influence in one region [10]. For America, even when it knows that the development of some nascent countries is irreversible, it still finds ways to prevent these countries' involvement in the middle East' affair. That scenario is just like several businessmen compete for a single region to make their company more profitable. For America, if it can control Iran and sever the sea passage which can transport oil, then China may have less opportunity to transport oil from the harbor of Iran and the separation will seriously damage the economy of China. Besides, Russia supports the Iran to fight for their own countries out of its own interests, so America chooses to oppose Iran to fight against Russia to emphasize its own position in the Middle East.

Thus, to some extent, the current situation in the Middle East is just like an epitome of the confrontation between America and China, Russia.

\subsection{The overall environment in the middle East}

The complex relationship between different groups in the middle East can make the U.S.-Iran relation more complex and irreconcilable. If you ascertain the complex relationship between countries in the middle east, then you will be a half politician. In the middle East, different races, different political parties and groups, different interests among politicians, all make the regional situation more volatile, intricate. In the chart below, we can realize the sophisticated and obscure relationship between different powers and countries in the middle East [11]. 


\section{Middle East Friendship Chart}

With overlapping civil wars in Syria and Iraq, a new flare-up of violence between Israel and the Palestinians, and tense nuclear talks with Iran, Middle Eastern politics are more volatile than ever and longtime alliances are shifting. Here's a guide to who's on whose side in the escalating chaos.

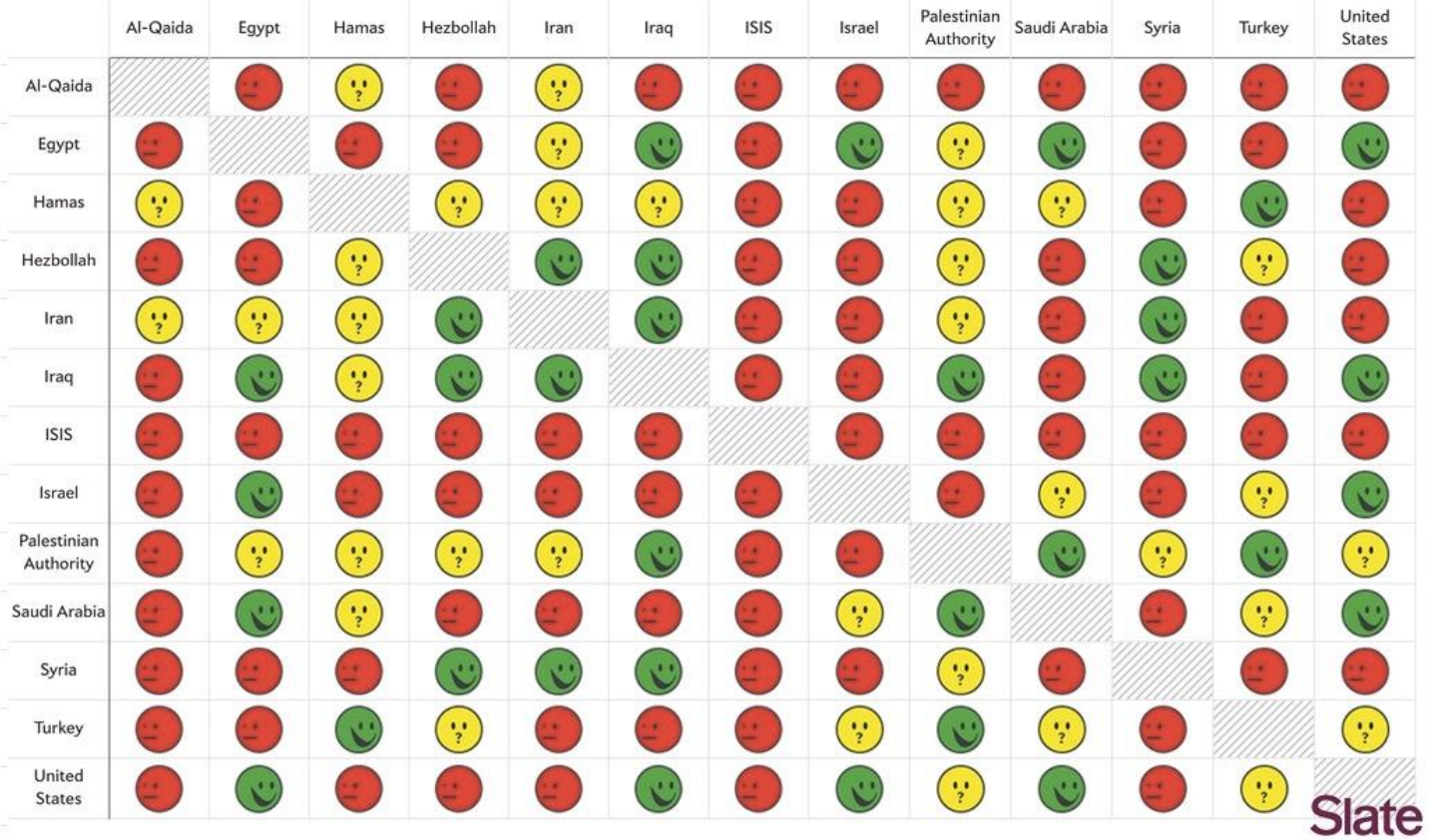

Figure 1. The Middle East Friendship Chart by Joshua Keating and Chris Kirk (2014)

From the chart above, we can find different relationships between these thirteen powers in this region. Al-Qaeda has a relative hostile relationship with other powers, except Hezbollah and Iran. ISIS is restricted by the other 12 powers mainly because it creates terrorism without any consideration of other country's interests. Israel has a favorable relationship with America and Egypt, while it dose not have such favorable relationship with the other powers. America power in this region has formulated its own favorable group, including Egypt, Iraq, Israel and Saudi Arabia, while it has an unclear relationship with Turkey and Palestine and a hostile relationship with Al-Qaeda, Hamas, Hezbollah, Iran, ISIS and Syria. For Iran, however, it has a favorable relationship with Hezbollah, Iraq and Syria, while it has an unclear relationship with al-Qaeda, Egypt, Hamas and Pelestine and a hostile relationship with ISIS, Israel, Saudi Arabia, Turkey and America. Some countries and powers have some mutual benefits, so they from a temporal collision. But the enemy of one ally may be the favorable partnership of another ally. We cannot easily find the tightest friendship between these thirteen forces in the middle East and we cannot predict whether the current relationship will change as the time goes by.

Therefore, different powers in the middle East have their own racial benefit, economical benefit, political benefit and religious benefit, which makes the middle East more turbulent and intractable, leading to a more complex interest chain between America and Iran.

\section{SOLUTIONS}

\subsection{Pushing for a deal to denuclearize Iran}

US and Iran should discard prejudice and make concessions. Just like six-party talks on north Korea's nuclear program, in which the international community cooperate with each other and hold some meetings to tackle this tough relationship together, US and its allies ought to abandon the long-term prejudice and bias toward Iran and do not only focus on their own interest. Conversely, they ought to consider why Iran proceeds nuclear test to revenge for the western world and protect its own country's safety. It is the military intervention in this region and the sanction from the international world that causes the military test of Iranian government. So for America, it ought to consider not only the problem of Iran, but also their high pressure measures in Iran.

Moreover, the regional cooperation and the international synergy can also contribute for the settlement of strained U.S.-Iran relation. From one point, because of the intervention from other countries and different interests no matter in religion and race, the middle East has been divided into heterogeneous groups and dominant places. It seriously blocks the cooperation between countries to eradicate the terrorism and mitigate the relationship between America and Iran. Although the whole procedure 
may be full of difficulties and uncertainty due to the persistent misunderstanding and prejudice, we should attempt to promote the reconciliation of the relationship between America and Iran as it is a reasonable way to stabilize the regional situation and mitigate the strained situation. If countries and regions in Middle East can establish a united organization, like the EU and ASEAN, it can employ the different power of different countries in the middle East and work together to prosper local economy and fight against terrorism [12].

Furthermore, all countries ought to work together to reach some substantial decision, such as the assistance to Iran, the forbidden of the research of nuclear weapons. And it is most favorable if they can formulate some regulations so that any country which violates this treaty will get punishment from the international world. Only by coordinating with all the shareholders, can we finally promote the reconciliation of Iranian problem. Although it is really hard due to the various interests from different political groups in the Middle East, they need to have a try to form a collision without the involvement of other countries to tackle the problem by themselves. Then the middle East can better develop their economy and the relationship between Iran and other countries can be mollified.

\subsection{Respecting the diversity of religion and value system}

In the international relationship, we need to respect the diversity of various value system and acknowledge the rationality of its existence. Every country has its own value system and ideal religion. We can not say that one value system is more superior than others. America and Iran both have their own validity in the value system. So they ought to consider the other side's opinion and forbid some prejudices. Nevertheless, if there is violation of world peace and international regulations, we ought to persevere the authority of the international regulation and prevent such disobedience [13].

So America should not always propagate its own value system to other countries and urge the middle East to adhere to its own value system. Instead, it ought to embrace the local value system as it has its own validity and reasons. Likewise, Iran should forgo its prejudice and bias toward America and other western countries' value system. Besides, Iran should work with the whole world to eliminate the terrorism and prohibit the propagation of some extreme ideology and extreme patriotism. Only by mutually respecting each other's value system, can America and Iran have some understanding of mutual interest and thus promoting the peace of the middle East.

\subsection{America Retreating armies from the middle East}

If America can retreat some armies from the middle East and do not intervene the situation of the middle East, it can decrease the complexity of the middle East and mitigate the strained relations between America and Iran.

Just like the Vietnam War, some American army has been caught in the middle East and American government has to allocate some resource to these armies and preserve the stability and security of its alliance and avoid the outbreak of the terrorism. From one point, all of these strained relations largely derived from the coercion policy of America. If America can decrease its intervention to the partial war and do not give assistance to some countries in the middle East, such as Israel, Saudi Arabia to fight against some hostile power, it can effectively decline the complexity of the situation in the Middle East and lesson Iran's confrontation toward America.

Moreover, if America can decrease its intervention in the middle East, then it can more focus on the local economy and develop its technology rather than wasting its military resource in the middle East. The true powerful of one country is not conquering other countries, but the contribution and assistance it can give to the whole world and other undeveloped countries.

\subsection{Infrastructure reconstruction and education assistance}

Numerous people in Iran has a low living quality and a low literal level, which seriously triger the unstability in Iran and the aggravation of U.S.-Iran relation [13]. If we can provide some facilities to Iran and help it to build up some schools, then the local people may receive a better education and do not tend to participate in the terrorism. They may more focus on their pleasant life rather than accepting some extreme ideology and research some nuclear weapons to fight against some western countries. And with more high-morality and more nurtured people, Iranian will have more patience to negotiate with the international world as it may feel that it has not been abandoned by the international world. Finally, it can mitigate the serious U.S.-Iran relations [14].

Moreover, some countries can send volunteers to Iran to proceed peace education. For Iranian, they may not know the importance of peace and the outcome of researching some WND. The consequence of the wheeler-dealer can only make the regional situation more complex and the relationship between Iran and the western world more nervous, disturbing the peace of the whole world. Only by providing some peace education to the local people, can Iranian, especially Iranian children, notice the significance of cooperation with the international world and preserving the whole peace of the world.

\section{CONCLUSION}

The nervous relationship between America and Iran is derived from some reasons no matter in economy, history, religion, politics, military and regional relationship. 
Moreover, the best solution to the austere relationship is that respecting each other's value system and decrease the intervention of the politics and economy of Iran and form the regional collision and formulate the related regulations to prohibit terrorism and focus on the development of the local economy and the improvement of literal level. By obeying such procedure can Iran and America become less antagonistic and the terrorism can be eradicated and the global peace can be preserved. According to the analysis in the article, we can even predict that the contradiction between these two countries can be mitigated through the joint efforts of the international community in the short term.

\section{ACKNOWLEDGMENT}

I want to express my thanks to Professor M.T. Bernhardson and directors from Cetus Talk Online here.

\section{REFERENCES}

[1] K. D. Groot. A history of U.S.-Iran relations [D] Penn Today, Arts, Humanities, \&Social Science. January 9,2020

[2] F.M. Reza; Markwardt,Gurther. The effects of oil price shocks on the Iranian economy [J] Dresden discussion paper series in economics, No.15/08

[3] A.Kitous, B. Savenyn, S. Gervais, T. Wiesenthal and A.Soria. Analysis of the Iran Oil Embargo [R] Jac

Scientific and Policy Reports. 2013

[4] M.R. Farzanegan and T. Krieger. Oil Revenues Shocks and Inequality in Iran [C] ERF's 24th Annual Conference(Cairo,2018), European Public Choice Society Annual Conference(Rome,2018), October 2018

[5] M.R. Farzanegan. Oil revenue shocks and government spending behavior in Iran [J] Energy Economics. Online 23 May 2011

[6] M. Asif, M.T. Khan. Possible U.S.-Iran Military Conflict and its Implications upon Global Sustainable Development [J] Journal of Sustainable Development

[7] H. Whitehouse. Dying for the group: Towards a general theory of extreme self-sacrifice [J] Behavior and Brain Sciences. 30 January 2018

[8] M. Mehrara, M. Musai, A.R. Karsalari. Oil Revenues, Economic Growth and Resource Curse in Iran economy [J] Journal of Social and Development Sciences, Vol.2,No,2,pp.73-80,Aug 2011(ISSN 2221-1152)
[9] R. Eslami-Somea\&H. Movassagh. Peace education in Iran: Challenges and Prospects [J] Journal of Peacebuilding\&Development, 9:2,33-48, DOL:10.1080/ 15423166. 2014. 948781

[10] L.A. Ali. Historic US-Iran Relations: Revisiting Ideology and Geostrategy [C] 10th American Studies Conference. October 2007

[11]

http://www.slate.com/blogs/the_world_/2014/07/17/the_mi ddle_east_friendship_chart.html

[12] C. Mahapatra. U.S.-Iran Nuclear Deal Cohorts and Challenger [J] Contemporary Review of the Middle East 3(1)36-46. 2016 Publications India

[13] H. Mousavian. An opportunity for a U.S.-Iran Paradigm Shift [J] The Washington Winter 2013

[14] M. Rouhi. U.S.-Iran tensions and the Oil Factor [J] Survival:Global Politics and Strategy. 60:5,33-40, DOL:10-1080/00396338.2018.1518367 